\title{
First report of reef formation from the Balkanide type of Triassic: the Tran Formation (Upper Triassic) near the village of Gorna Sekirna, SW Bulgaria
}

\section{Първи доказателства за рифообразуване от Балканидния тип Триас: Трънската свита (Горен Триас) при с. Горна Секирна, ЮЗ България}

\section{Athanas Chatalov \\ Атанас Чаталов}

Sofia University “St. Kliment Ohridski”, 15 Tsar Osvoboditel Blvd., 1504 Sofia; E-mail: chatalov@gea.uni-sofia.bg

\begin{abstract}
Sphinctozoa skeletons were the main builders in microbial-sponge boundstones and cementstones. Syndepositional lithification of associated automicrite and marine phreatic cementation by radial fibrous and radiaxial calcite favored stabilization and growth of skeleton-cement reefs across a central reef area (close to a platform margin), but without forming a wave-resistant reef framework. Storm-influenced destruction of the buildups and subsequent reworking by waves and currents produced bioclastic-intraclastic grainstones.
\end{abstract}

Keywords: microbial-sponge boundstone/cemenstone, Sphinctozoa, automicrite, skeleton-cement reef.

Сред всички фациални типове Триас Балканидният тип има най-голямо разпространение на територията на България (Čatalov, 1991). Морските карбонатни седименти в него са сравнително добре изучени и включват фациеси, които са отложени в различни подотливни, междуприливно-отливни и надприливни обстановки. Досега в литературата няма представени убедителни данни за протекло рифообразуване, въпреки някои изказани предположения (например, Belivanova, 1996).

Извършени нови седиментоложки изследвания в Ерулска планина, намираща се южно от град Трън, дават категорични доказателства за образуване на рифогенни постройки в скалите на въведената от Tronkov (1983) Трънска свита, която има къснотриаска (Карнско-Норска) възраст. Изследваният разрез на тази единица се простира по южния склон на планински рид с най-висока точка Големи врьх, непосредствено на север от с. Горна Секирна. В него Трънската свита има видима дебелина около $120 \mathrm{~m}$, като нейната подложка е представена от среднотриаски варовици на Радомирската свита, а горната й граница е тектонски контакт с кластични скали на Костелската свита (Кимеридж-Бериас). Скалната последователност е изградена изцяло от светлосиви и сивобелезникави варовици, които се характеризират с дебело- до грубопластова стратификация и масивна текстура.

Данните, получени от микропетрографския анализ на 42 проби, показват преобладаване на три микрофациални типа (МФ): микробиално- спонгиев баундстоун, микробиално-спонгиев циментстоун и биокластично-интракластичен грейнстоун. Първите два МФ са изградени от следните структурни елементи: калциспонгии, микробиални кори, Tubiphytes, микритен матрикс, биокласти и спойки. Спонгиите имат твърд скелет от $\mathrm{CaCO}_{3}$ и принадлежат към т. нар. хиперкарцифицирани спонгии. Според своите морфоложки характеристики почти всички спонгиеви скелети притежават сегментиран строеж, и следователно се отнасят към групата Sphinctozoa. Микробиалните кори (microbial crusts), които се отличават с различни размери и форма, се разполагат сред микритния матрикс или на границата между него и съседни участъци със спойка. Те са ламинирани, като показват хомогенен микропелоиден строеж, или са формирани от редуващи се ламини с микрит и микроспар (тип Spongiostromata). Матриксьт също има преобладаващо микропелоиден строеж и на места изпълва вътрешността на калциспонгии. В него се съдържат редки Tubiphytes и биокласти (остракоди, криноиди, бивалвии, гастроподи, фораминифери). Последният структурен елемент обхваща бивши празнини (с големина до $4 \mathrm{~mm}$ и главно неправилна форма), които са запълнени последователно с радиална влакнеста (или радиаксиална) и блокова спойка, като дебелината на първата генерация цимент е значително по-голяма при радиаксиалния тип. Освен това нерядко се наблюдава редуване на две или повече генерации от радиаксиална спойка, които могат да бъдат разделени от тънки ивици 
микрит. Участыците с калцитен цимент се разполагат директно до микритния матрикс, микробиални кори, както и във вътрешността на скелети от Sphinctozoa. Разликата между баундстоуните и циментстоуните се свежда до това, че при вторите спойките преобладават количествено в скалната структура. Грейнстоуните са изградени от интракласти и биокласти в приблизително равно количество, с предимно умерена сортировка и повишена степен на заобленост, като са споени от радиалновлакнест и блоков клацит. Интракластите произхождат почти изцяло от предходните два МФ, като достигат размери от 1,7 mm. Болшинството от тях включват останки от калциспонгии, на места с участието на матрикс, а останалите са изградени от микрит и/или микробиалити плюс фрагменти от Tubiphytes. Разнообразната фосилна асоциация в грейнстоуните е представена от бивалвии, брахиоподи, криноиди, зелени водорасли, фораминифери, гастроподи, ехиниди и остракоди. В изследвания разрез на Трънската свита се установяват също единични проби от други пет МФ: пелоидно-биокластично-интракластичен пакстоун, пакстоун с добре заоблени интракласти, брахиоподно-интракластично-криноиден пакстоун, биокластично-пелоидно-интракластичен вакстоун/флоутстоун и биокластичнопелоиден вакстоун с микробиалити.

Относително малкият размер, незакономерното разположение и често изолираният характер на цели скелети от Sphinctozoa в структурата на баундстоуните и циментстоуните, са показателни за свободен колониален растеж на тези организми, но без самостоятелно образуване на твърда, вертикална рифова структура (framestone, true reef, frame reef). Калциспонгиите са били главни конструктивни елементи (main/primary builders) в изграждането на карбонатни постройки, докато микробиалните кори от типа Spongiostromata и микроинкрустиращите Tubiphytes ca имали второстепенно значение (accessory/secondary builders). Постоянното присьствие на различно количество матрикс с редки биокласти в скалите показва, че спонгиите са играли допълнително ролята на прегради (baffling) спрямо морски течения и вълнение, което е спомогнало за механичното улавяне (trapping) на алохтонен седиментен материал в междускелетното пространство. От своя страна, микробиалните кори и част от матрикса (с микропелоиден строеж) очевидно се явяват продукт на микробиално индуцирано карбонатно утаяване, т.е. формиране на автомикрит според терминологията, предложена от Reitner and Neuweiler (1995). Налице са ясни доказателства, че автомикритът е претърпял бърза, т.е. синседиментационна литификация, като например, разполагането му по периферията на праз- нини (запълнени по-късно изцяло или отчасти с морски фреатични спойки) или между различни генерации от такива цименти. Следователно, ранната литификация на автомикрита е била един от факторите, който е допринесъл за стабилизацията и растежа на карбонатните постройки. Аналогичен ефект е имало отлагането в междускелетни и вътрешноскелетни пори на радиална влакнеста и радиаксиална спойка. Синседиментационният характер на това спояване се доказва от локалното редуване на отделни генерации цимент с автомикрит, често проявения изопахитен характер на спойките, както и разполагането на т. нар. вътрешен седимент в централната част на празнините, т.е. микрит, отложен след приключване на циментацията. По този начин ранното спояване също е спомогнало за бързо заздравяване и стабилизация на постройките, независимо от темповете на растеж на спонгиеви скелети и Tubiphytes, образуването на автомикрит и механичното улавяне на седиментен материал. Самото отлагане на спойките е било пряко свързано както с наличието на ефективна първична порестост, така и с активна и постоянна циркулация на морска вода през карбонатните постройки, т.е. умерена до висока хидродинамика. Освен от тези два фактора, относителното количество цимент в баундстоуните и циментстоуните е било контролирано от различните темпове на растеж на самите скелетни постройки (т. нар. карбонатна продуктивност), като отлагането на повече спойка е било благоприятствано от по-ниска такава продуктивност. Други параметри на седиментационната среда са били нормална морска соленост, окислителен режим, отсъствие на силицикластичен привнос и олиготрофни до слабо мезотрофни условия. В частност, наличието на микробиалити (цианобактерия) и Tubiphytes свидетелства за относително ниски темпове на седиментация и плитка водна дълбочина, най-вероятно в рамките на фотичната зона. Карбонатните постройки (включващи баундстоуни и циментстоуни) могат да се категоризират като скелетно-циментни рифове (skeleton-cement reefs) според класификацията на органичните рифове, предложена от Riding (2002). В този тип рифогенни постройки синседиментационните спойки стабилизират калцифицирани организмови скелети, осигурявайки субстрат за техния по-нататъшен растеж. В конкретния случай, спойките имат приблизително еднакво значение в баундстоуните и подчертано водеща роля в циментстоуните за структурното поддържане, в сравнение със съвкупността от спонгиеви скелети, матрикс и микробиалити. Асоцииращите в разреза грейнстоуни съдържат интракласти, които произхождат от дезинтеграцията на полулитифицирани баундстоуни и вероятно циментстоуни. Повише- 
ната степен на сортировка и заобленост на алохемите, промитият характер на утайките и спояването с радиалновлакнест цимент са показателни за образуване във високоенергийна обстановка. На свой ред, стенохалинната фосилна асоциация е индикатор за нормална соленост на морската вода, а присъствието на дацикладацеи свидетелства за отлагане над нормалния вълнови базис. Останалите МФ в Трънската свита, включващи пакстоуни и вакстоуни/флоутстоуни, са изградени от разнообразни интракласти, биокласти и пелоиди. Наличието на преобладаващо заоблени алохеми, богата скелетна фауна, фрагменти от Tubiphytes и дацикладацеи, микробиалити с Girvanella и интракласти с Cayeuxia дава основание да се интерпретира плитководна седиментация в условия на променлива (главно умерена) придънна хидродинамика, окислителен режим и нормална соленост.

Редуването в разреза на преобладаващи баундстоуни, циментстоуни и грейнстоуни е показателно за периодичното развитие на рифогенни постройки и тяхното последователно разрушаване. При анализа на получените данни не се установяват доказателства за наличието на рифов платформен ръб (reef platform margin), прехождащ към дълбоководен басейн посредством рифов фронт, предрифова зона и склонови отложения, като например формирането на твърда, вертикална рифова рамка и рифови брекчи. От друга страна, образуването на специфичния тип скелетно-циментни рифове през Средния и Късния Триас се свързва принципно с обстановка на платформен ръб/горен склон, където са налице благоприятни условия за морско фреатично синседиментационно спояване. Следователно, в дадения случай може да се допусне съществуването на плитководна, централна рифова площ (central reef area), която е била разположена в непосредствена близост до или върху такъв платформен ръб, но без оформянето на бариерен риф с топографски издигнат релеф, големи размери и характерна зоналност. В рамките на въпросната рифова площ най-вероятно са се развивали самостоятелни рифогенни постройки (patch reefs), които не са притежавали вълново-устойчива рифова рамка. На свой ред, биокластичноинтракластичните грейнстоуни биха могли да се интерпретират като близко разположен, плитководен задрифов фациес и/или високоенергийни отложения, акумулирани между отделните рифови постройки. Периодичното разрушаване на баундстоуни и циментстоуни в централната рифова площ е било свързано предполагаемо с щормови събития, докато механичната преработка на рифовия детритус (съпроводена с известен транспорт) и смесването му с разнообразни не- рифови биокласти, са протичали под влиянието на нормална вълнова дейност и морски течения.

Въпреки че са известни още от Анизкия етаж, рифогенни отложения с водещото участие на калциспонгии (Sphinctozoa) са установени главно в горноладинско-долнокарнски скали, отразявайки един интервал от Триаския период, който в литературата е наричан първи триаски рифов оптимум (Flügel, 2002). В тази посока могат да се посочат редица подобни примери от различни части на Западния Тетис, а така също западната и източната част на Панталаса. Същевременно, отделни находки на варовици, доминирани от калциспонгии, са документирани и от по-млади триаски, т.е., горнокарнски, норски и ретски отложения. От направеното сравнение по литературни данни може да се заключи, че найблизките аналози на установените в Трънската свита баундстоуни, циментстоуни и грейнстоуни са описани от ладинско-карнски рифогенни скали в южната част на Апенините (Boni et al., 1994) и Северните варовикови Алпи в Бавария и Тирол (Rüffer, Zamparelli, 1997).

Настоящото изследване представя първите седиментоложки доказателства за рифообразуване в морски скали на Балканидния тип триас. Освен това за пръв път у нас са установени и описани циментстоуни, баундстоуни с микробиалити и преобладаващи калциспонгии, както и карбонатни постройки от типа скелетно-циментен риф. Следва да се отбележи, че последните се нареждат сред сравнително малкото известни от литературата фанерозойски находки на този специфичен тип рифове, които включват няколко примера от палеозойски, триаски и горноюрско-долнокредни скали.

\section{Литература \\ References}

Belivanova, V. 1996. Sedimentology of the Trun Formation north of the town of Trun. - Rev. Bulg. Geol. Soc., 57, 1924 (in Bulgarian with English abstract).

Boni, M., A. Iannace, M. Torre, V. Zamparelli. 1994. The Ladinian-Carnian reef facies of Monte Caramolo (Calabria, Southern Italy). - Facies, 30, 101-117.

Čatalov, G. 1991. Triassic in Bulgaria - a review. - Bull. Techn. Univ. Istanbul, 44, 103-135.

Flügel, E. 2002. Triassic reef patterns. - In: Flügel, E., W. Kiessling, J. Golonka (Eds.). Phanerozoic Reef Patterns. Society for Sedimentary Geology (SEPM), 391-463.

Reitner, J., F. Neuweiler. 1995. Mud mounds: a polygenetic spectrum of finegrained carbonate buildups. - Facies, 32, 1-69.

Riding, R. 2002. Structure and composition of organic reefs and carbonate mud mounds: concepts and categories. Earth-Sci. Rev., 58, 163-231.

Rüffer, T., V. Zamparelli. 1997. Facies and biota of Anisian to Carnian carbonate platforms in the Northern Calcareous Alps (Tyrol and Bavaria). - Facies, 37, 115-136.

Tronkov, D. 1983. Stratigraphic problems of Iskar Carbonate Group (Triassic) in South-west Bulgaria. - Geologica Balc., 13, 91-100 (in Russian with English abstract). 